\title{
EARLY EFFECTS OF FAT INGESTION ON LIPIDS AND LIPO- PROTEINS OF SERUM IN MAN
}

\author{
BY RICHARD J. HAVEL 1 \\ (From the Laboratory of Cellular Physiology and Metabolism, National Heart Institute, \\ Bethesda, Md.)
}

(Submitted for publication January 21, 1957; accepted February 28, 1957)

The mechanisms of fat transport in the blood are still poorly understood. Recent studies have shown that all lipids in blood plasma exist as lipoprotein complexes, that a broad spectrum of such complexes exists, and that groups of these complexes can be separated from each other by various physical means. Application of these separation methods to the study of chemical changes within lipoprotein classes should provide greater understanding of fat transport.

The chylomicronemia produced by ingestion of fat in man is accompanied chiefly by an increased concentration of triglycerides, the chief components of chylomicra $(1,2)$ in the serum. Phospholipid concentration also increases significantly (3), but free and ester cholesterol concentrations increase slightly $(4)$ or not at all $(5,6)$. No changes have been reported in the concentrations in serum of high density and $S_{\mathbf{t}}$ 0-30 classes of lipoproteins after ingestion of fat, but the concentration of the higher $S_{\mathbf{t}}$ classes increases. There appears to be a progressive shift with time in the concentrations of these very low density lipoprotein classes in the direction of greater density (7). Chylomicra and lipoproteins of high $\mathrm{S}_{\mathrm{f}}$ rates consist chiefly of triglycerides with lesser quantities of phospholipids, cholesterol esters, unesterified cholesterol, and protein (8). Thus, the serum lipid changes found after ingestion of fat might be explained exclusively by increased concentrations of chylomicra and lipoproteins having $S_{\mathbf{f}}$ rates exceeding 30.

To define further the effects of ingestion of fats on serum lipids and lipoproteins, alterations in various lipid constituents of ultracentrifugally separated lipoprotein classes of serum were measured in healthy young adults following the ingestion of high fat meals. These studies have shown

\footnotetext{
1 Present address : Department of Medicine, University of California School of Medicine, San Francisco, California.
}

that the concentrations of major chemical constituents of both high and very low density lipoproteins in serum are increased after ingestion of fat.

\section{METHODS}

Experimental subjects. Healthy young adults, who had undergone thorough physical and laboratory examinations and who had no apparent systemic disease, were hospitalized in a metabolic ward. Other subjects were professional and technical personnel who were not examined but who had no known systemic disease.

Diets. Hospitalized subjects were given measured diets containing varying quantities of fat. After a 12 to 15-hour fast, they were given high fat breakfasts containing 1.5 gram of fat per $\mathrm{kgm}$. of body weight as calculated from standard tables. The composition of these meals is listed in Table I. Occasional transient nausea was the only apparent adverse effect of eating this quantity of fat. The subjects were allowed water but no food during the next 8 hours. Between the eighth and tenth hour they were given a supper supplying 10 calories per $\mathrm{kgm}$. of body weight which contained practically no fat. Only water was permitted thereafter until completion of the test.

Blood samples and analytical procedures. Blood samples were taken from an antecubital vein and allowed to clot. The serum was extracted with ethanol-acetone $(1: 1 \mathrm{v} / \mathrm{v})$ or chloroform-methanol $(2: 1 \mathrm{v} / \mathrm{v})$. Two $\mathrm{ml}$. of serum contained in a calibrated hypodermic syringe was forcefully ejected into about $45 \mathrm{ml}$. of solvent through a 23-gauge needle, and additional solvent added to give a final volume of $50 \mathrm{ml}$. Analyses for cholesterol (9), lipid phosphorus (10), and total lipid (11) were done directly on the ethanol-acetone extract after the precipitated proteins had been centrifuged down. The chloroformmethanol extract was treated further by a modification of the procedure described by Sperry and Brand (12). The extract was separated into two phases by the addition of $10 \mathrm{ml}$. of distilled water. The two phases were mixed by inversion and allowed to separate overnight. The upper phase contains the crystalloids of serum, and the lower phase the lipids. The final volume of the lower phase was $36 \mathrm{ml}$.

Direct comparison of results obtained by the two extraction procedures demonstrated that the yields of total and free cholesterol and of lipid phosphorus were identical, 
TABIE I

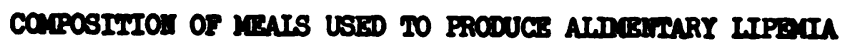

\begin{tabular}{|c|c|c|c|}
\hline real no. & composition per Kon. & Body We1ght & Preparation \\
\hline 1 & $\begin{array}{l}36 \% \text { crean } \\
\text { skirmed nill } \\
\text { cocos } \\
\text { sucrose }\end{array}$ & $\begin{array}{l}4.0 \mathrm{ml} . \\
4.0 \mathrm{ml} . \\
0.12 \mathrm{gm} . \\
0.25 \mathrm{gm} .\end{array}$ & howogentzed \\
\hline 2* & $\begin{array}{l}\text { whole egs } \\
\text { olecmargarine } \\
\text { bacon, ling fried }\end{array}$ & $\begin{array}{l}4.5 \mathrm{gm} . \\
0.8 \mathrm{~cm} . \\
0.5 \mathrm{gm} .\end{array}$ & $\begin{array}{l}\text { egg beaten in } \\
\text { melted oleo- } \\
\text { margine and } \\
\text { fried }\end{array}$ \\
\hline 3 & $\begin{array}{l}\text { corn oll } \\
\text { skimmed mill pouder } \\
\text { sucrose } \\
\text { water } \\
\text { vanilla (to flavor) }\end{array}$ & $\begin{array}{l}1.5 \mathrm{gm} . \\
0.5 \mathrm{gm} . \\
0.15 \mathrm{gm} . \\
3.0 \mathrm{ml} .\end{array}$ & homogentzed \\
\hline
\end{tabular}

- Contains only about $0.05 \mathrm{gm}$. carbohydrate

whereas the calculated triglyceride content (11) was about $100 \mathrm{mg}$. per $100 \mathrm{ml}$. of serum higher in the ethanolacetone extract. This results from the fact that certain crystalloids, principally chloride ion, contaminate the ethanol-acetone extract and contribute to the apparent total lipid concentration. Consequently, $100 \mathrm{mg}$. has been subtracted from all triglyceride values obtained by this method. Crystalloids are practically absent from the chloroform-methanol extract. Unesterified fatty acids are distributed between the two phases of this extract (13), but virtually no other lipids are present in the polar phase. "Triglyceride" values given for the chloroformmethanol extract therefore represent glyceryl esters of fatty acids (chiefly triglycerides [14]) plus a portion of the unesterified fatty acids.

Separation and analysis of lipoprotein fractions. Lipoprotein fractions were separated from serum as described previously (15). The densities and nature of the fractions are given in Table II. Aliquots of Fraction I + II were extracted in chloroform-methanol. The other fractions were extracted in ethanol-acetone. Since Fraction I + II contains about 50 per cent triglycerides and practically no unesterified fatty acids (13), triglyceride values for this fraction are considered to be more accurate than those obtained on whole serum. Analyses were done as on whole serum.

\section{RESULTS}

\section{Serum lipids}

The initial studies were carried out on subjects in a metabolic ward to determine the effects of previous diet on the nature and duration of hyper-

TABIS II

ULARACENIRIFUGAIIY SEPARATED ITPOPROTEIN FRACTIOIS

\begin{tabular}{|c|c|c|c|}
\hline Fraction & Nomenclature & Dens1ty & $\begin{array}{l}\text { Blectrophoret1c } \\
\text { Mobility } \\
\text { (otarch) }\end{array}$ \\
\hline$I+I I$ & $\begin{array}{l}\text { Very low density lipoproteins, } \\
\text { Including chylomicrons } \\
(\text { se }>10)\end{array}$ & $<1.019$ & $\begin{array}{l}\text { Alpha -2 } \\
\text { Blobulin }\end{array}$ \\
\hline III & $\begin{array}{l}\text { Low density lipoproteins } \\
\text { (st } 0-10)\end{array}$ & $1.019-1.063$ & $\begin{array}{l}\text { Beta-1 } \\
\text { Blobulin }\end{array}$ \\
\hline $\mathbf{T v}$ & H1gh density lipoproteins & $1.063-1.21$ & $\begin{array}{l}\text { Alpha-1 } \\
\text { globulin }\end{array}$ \\
\hline $\mathbf{v}$ & $\begin{array}{l}\text { Unesterifled fatty acids } \\
+ \\
\text { Residual serum proteins }\end{array}$ & $>1.21$ & $\begin{array}{l}\text { Albumin } \\
+ \\
\text { All components }\end{array}$ \\
\hline
\end{tabular}


lipemia following ingestion of fat. Four subjects were given, in succession, isocaloric diets which contained 1.0, 0.1 and 2.0 grams of fat per $\mathrm{kgm}$. body weight. The first diet was maintained for 2 weeks, and the second and third for 1 week each. Fat breakfast No. 1 was given at the end of each week of study. The results, tabulated in Table III, show that the magnitude of the increment in serum triglyceride concentration was not related consistently to the nature of the diet during the week preceding the test; however, the hyperlipemia frequently persisted longer when the subjects were given the high and low fat diets than when they received the moderate fat diet. Of further interest is the fact that the serum triglyceride concentration was usually lower 12 hours after the fat meal than just before or 24 hours after its ingestion, regardless of the fat content of the diet. For all diets the mean triglyceride concentration at 12 and 24 hours, respectively, was 56 and $79 \mathrm{mg}$. per 100 ml. of serum, with a probability of less than 0.01 that the difference observed was the result of

TABIE III

ALTERATIONS IN WHOIS SERUA IIPID CONCENTATIONS FOLOWIKG INCESTION OF 1.5 G. CREAM FAT PER Kg. BODY WETCHT

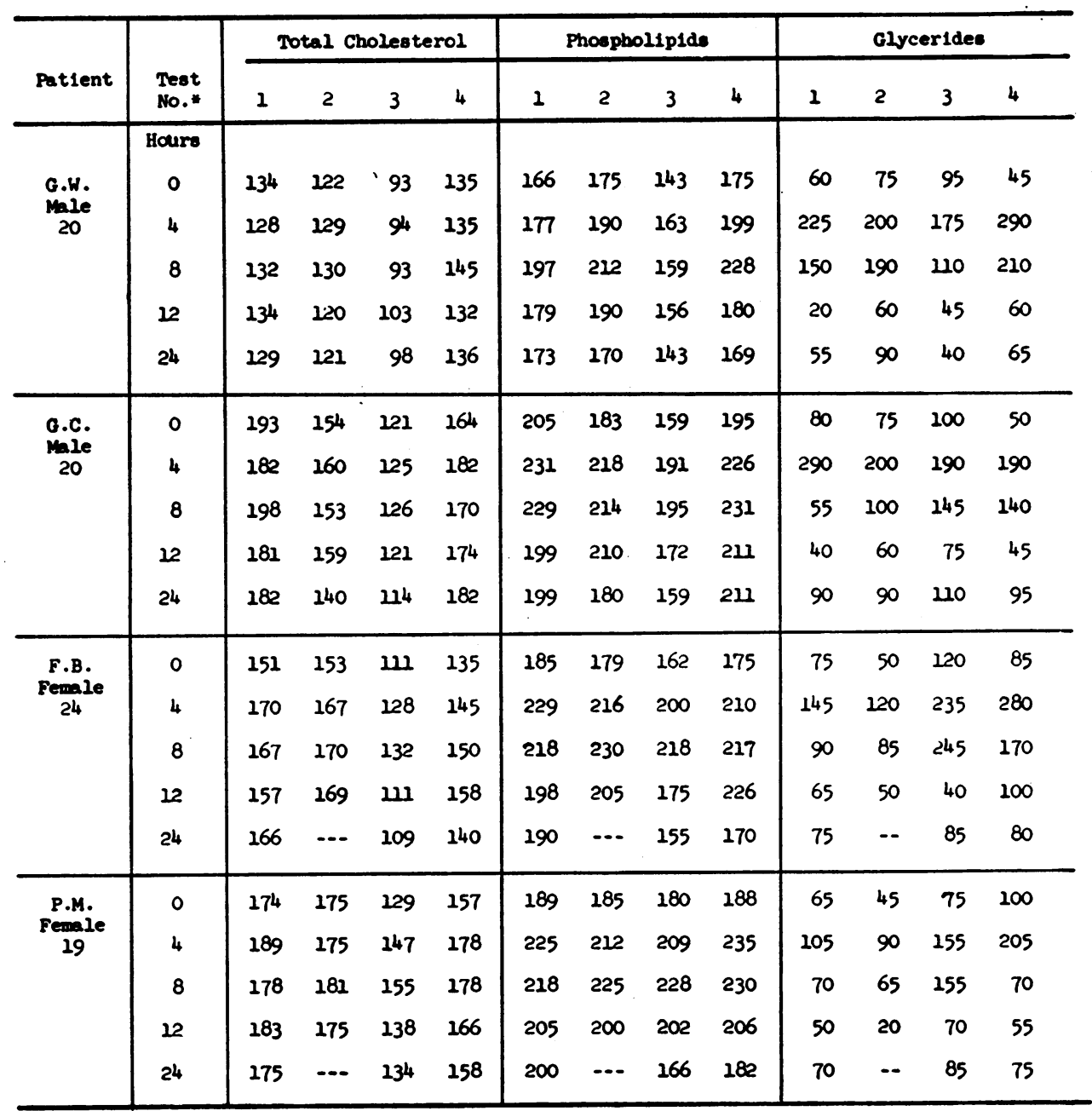

- Test 10. 1: On 180caloric diet containing 1 go. fat per kg. body welght for 1 week Teot Ho. 2: On 1socalorlc diet contalning 2 gin. fat per kg. body welght for 2 veeks Test No. 3: On 180caloric diet contalning 0.1 gin. fat per kg. body weleht for 2 week Teet No. 4: On 1eccaloric diet contalning 2 o. fat per kf. body weleht for 1 week 
chance. The concentration of phospholipids rose uniformly and significantly during fat absorption. The increment in phospholipid concentration was not related consistently to the increment in concentration of triglycerides, and phospholipid concentration usually remained elevated after triglyceride concentration had returned to baseline, or lower, values. Twelve hours after the ingestion of fat, triglyceride concentration was below the baseline value 13 times in 16 tests, whereas phospholipid concentration was more than $12 \mathrm{mg}$. per 100 $\mathrm{ml}$. of serum higher than the baseline value 14 times in 16. The concentration of total cholesterol in the serum usually showed no consistent increase in the two male subjects. In the females cholesterol concentration rose at least $15 \mathrm{mg}$. per $100 \mathrm{ml}$. of serum following 7 of the 8 fat meals.

\section{Lipoprotein fractions}

Five additional subjects who were not on measured diets were studied after the ingestion of a single high fat meal. Meals No. 1 and 2 were

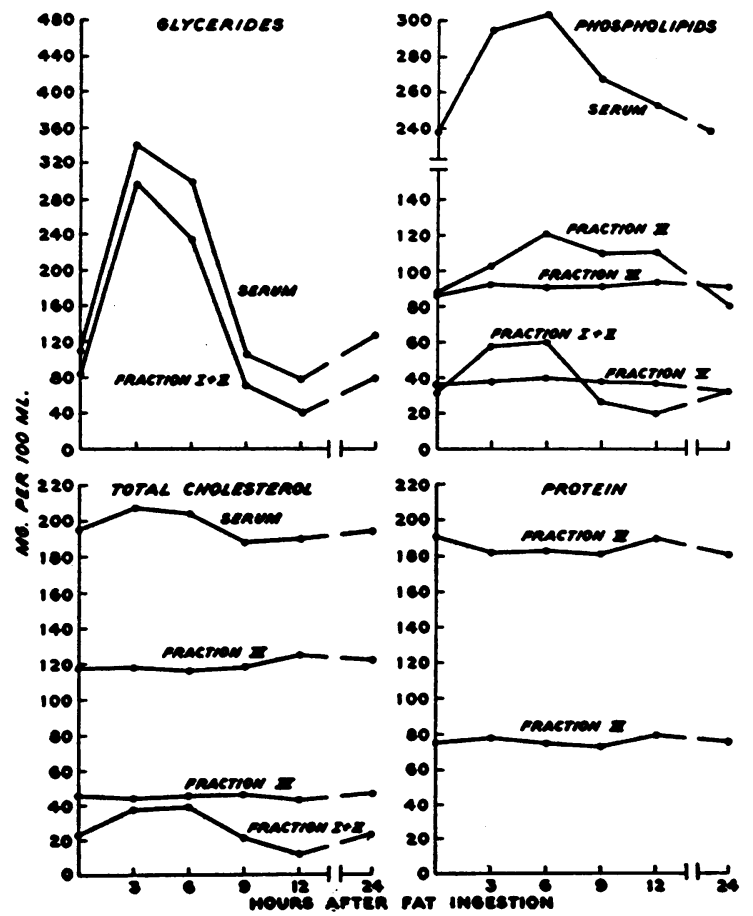

Fig. 1. Alterations in the Concentrations of Seruse Lipids and Chemical Constituents of Serun Lipoprotein Fractions Following Ingestion of 1.5 Gray of Fat Per KGM. Body Weight in a Healthy Adult
FRACTION I + I LIPOPROTEINS
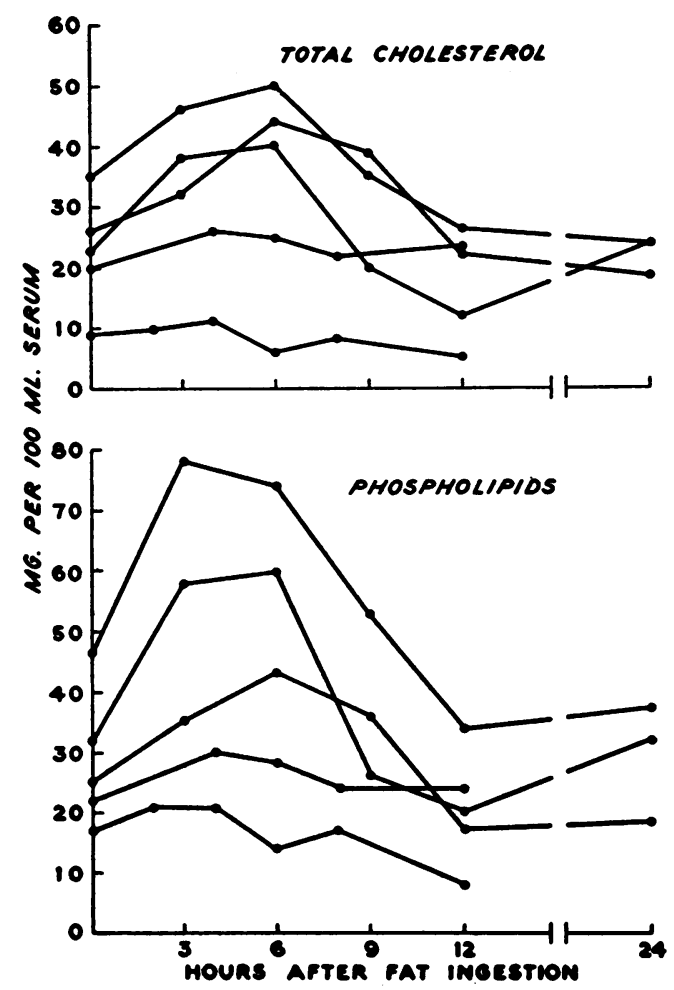

Fig. 2. Alterations in the Concentrations of Chemical Constituents of Serum Lipoprotein Fractrons following Ingestion of 1.5 Gram of Fat Per Kgm. Body Weight in Five Healthy Adults

used twice, and meal No. 3 once. The design of the experiments was the same as in the 4 subjects studied previously. Lipoprotein fractions were separated from aliquots of each serum sample and analyzed for lipid and protein constituents. Similar alterations in the various fractions were observed with the three types of fat-rich meal. Detailed results of one study are shown in Figure 1. The significant features are: 1) Alterations in serum triglyceride concentration reflected solely changes in triglycerides of Fraction I + II; 2) changes in serum total cholesterol concentration were relatively slight, but the small quantity of cholesterol in Fraction I + II was almost doubled; 3 ) changes in serum phospholipid concentration reflected the sum of changes in Fractions I + II and IV, and the elevation of Fraction IV persisted longer than that of Fraction I + II ; 4) changes in protein concentration in Fractions III and IV were slight; 5) changes in the three major lipid 
FRACTION III LIPOPROTEINS

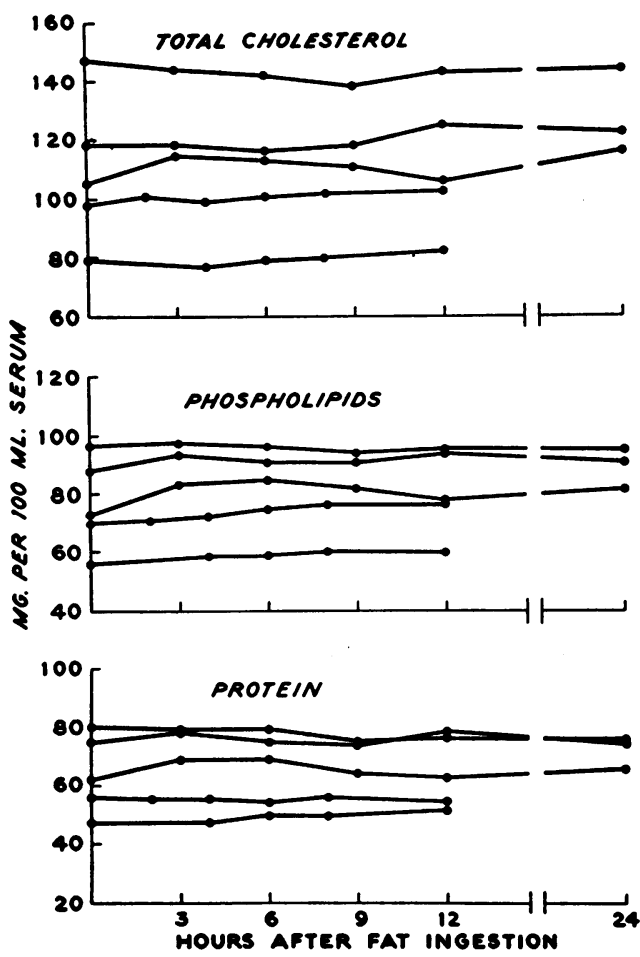

Fig. 3. See Legend, Figure 2

components of Fraction I + II tended to parallel each other, but the fall in the concentration of triglycerides preceded that of cholesterol and phospholipids; 6 ) the concentrations of Fraction I + II components were lower after 12 hours than after 24 hours. Alterations in measured components of the lipoproteins of the five subjects are shown in Figures 2 to 4. Although not shown in the figures, the magnitude of the increments in serum and Fraction I + II triglyceride concentrations tended to parallel that of the other lipid constituents of this fraction. Alterations in the concentrations of components of Fraction III were slight. In Fraction IV, phospholipid concentration rose consistently and tended to remain elevated 12 hours after the ingestion of fat, whereas total cholesterol and protein concentrations rose in only 3 of the 5 tests. The ratio of cholesterol to phospholipid in this fraction fell during fat absorption.

\section{DISCUSSION}

The demonstration that the increment in serum triglyceride concentration after ingestion of fat

is contained entirely in chylomicra and/or very low density lipoproteins is in accord with current concepts of exogenous fat transport. It has been shown previously in dogs by Swank and Wilmot (16) and in man by van Eck, Peters, and Man (17) that the bulk of the increment in serum triglyceride concentration after the ingestion of fat can be layered on the surface of the serum by relatively gentle centrifugation. In their studies no layering of cholesterol or phospholipids was demonstrated, although later studies have shown that equivalent centrifugation layers some of the cholesterol and phospholipids of human chyle (18), a result to be expected from the known composition of chylomicra (8). The present results neither support nor contradict the concept that chylomicra are degraded in blood plasma with the production of progressively higher density lipoproteins (7), but the fact that the concentration of cholesterol and of phospholipids in Fraction I + II sometimes fell later than that of the triglycerides is consistent with such an interpretation.

FRACTION II LIPOPROTEINS

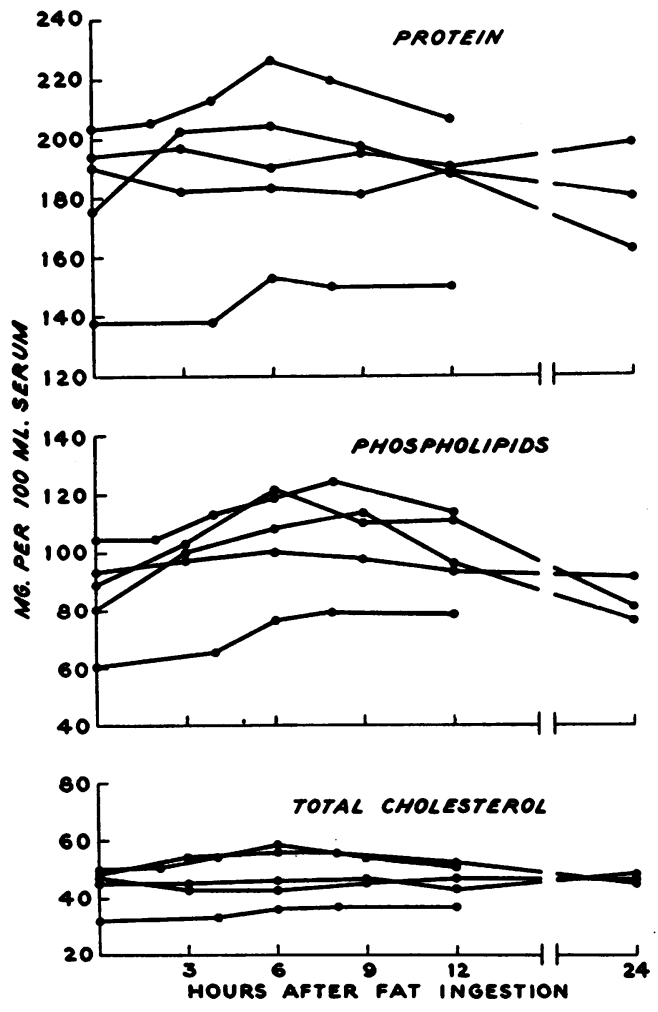

Fig. 4. See Legend, Figure 2 
The delayed fall in the concentration of serum phospholipids following ingestion of fat is clearly the result of increased phospholipid concentration in high density lipoproteins ( $c f$. Figure 1). This finding is not in accord with current concepts of lipoprotein alterations during transport of exogenous fat in the blood, although Swank and Wilmot found that the increased concentration of phospholipids in the serum of dogs absorbing fat remained in the infranatant serum after flotation of chylomicra (16).

The mechanism of the rise in phospholipid concentration in high density lipoproteins is unknown. Net transfer of phospholipid from Fraction I + II appears unlikely since there was no similar increase in phospholipid of Fraction III lipoproteins. That the increment resulted from an augmented rate of transfer of high density lipoproteins from thoracic duct lymph also appears unlikely because the other constituents of this fraction frequently showed no increase. It seems most probable that the changes observed are related to the further metabolism of exogenous fatty acids after they first leave the blood stream. It has been shown previously in dogs transfused with chylomicra obtained from lymph of dogs fed palmitic acid-1-C $\mathrm{C}^{14}$ that radioactivity in phospholipids of high density lipoproteins continues to increase after the disappearance of the chylomicra from the plasma (19).

The data presented suggest that previous diet may have some effect on the rate of absorption of ingested fat or on the rate of its removal from the blood; however, no firm conclusions can be drawn from the limited data available. The striking reduction in the concentration of serum cholesterol and phospholipids observed in four young adults after one week on an isocaloric diet containing practically no fat confirms previous observations (20-22). Unfortunately, data regarding the participation of the various lipoprotein fractions in this change were not obtained.

The lowest concentrations of triglycerides and very low density lipoproteins observed in this study (12 hours after ingestion of fat) occurred 3 to 4 hours after a fat-free meal. This raises the possibility that the availability of energy from sources other than fat may influence the concentration of these lipoproteins. This problem is the subject of the succeeding paper.

\section{SUMMARY}

1. The effects on serum lipids and ultracentrifugally separated lipoprotein fractions of the ingestion of fat-rich meals were studied in healthy young adults.

2. The increment in the concentration of triglycerides in the serum following ingestion of fat was entirely the result of an increase in their concentration in very low density $\left(S_{t}>10\right)$ lipoproteins. The cholesterol and phospholipid concentrations in this lipoprotein fraction also increased significantly and tended to parallel the triglyceride concentration. These changes were usually maximal 4 hours after the ingestion of fat.

3. Increments in the concentration of cholesterol in the serum after ingestion of fat were usually slight because the increment in the very low density lipoproteins represents only a small fraction of the serum value and the cholesterol concentration of the other fractions usually changes very little.

4. Serum phospholipid concentration increased significantly following ingestion of fat and frequently remained elevated after the serum triglyceride concentration had returned to baseline, or even lower, levels. The increase reflected changes in both the very low density and high density lipoprotein fractions. The delayed fall was the result of the persistence of the increased concentration of high density lipoprotein phospholipids after the visible lipemia had disappeared. Lesser increases in the concentration of high density lipoprotein cholesterol and protein may also occur after ingestion of fat.

5. These findings are discussed in relation to current concepts of exogenous fat transport.

\section{REFERENCES}

1. Cunningham, R. N., and Peters, B. A., Chemical nature of the ultramicroscopic particles of serum. Biochem. J., 1938, 32, 1482.

2. Elkes, J. J., Frazer, A. C., and Stewart, H. C., The composition of particles seen in normal human blood under dark-ground illumination. J. Physiol., $1939,95,68$.

3. Man, E. B., and Gildea, E. F., The effect of the ingestion of a large amount of fat and of a balanced meal on the blood lipids of normal man. J. Biol. Chem., 1932, 99, 61.

4. Brun, G. S., Changes in the lipide contents of serum in patients with manic-depressive psychosis. Acta psychiat. et neurol., 1940, suppl. 22. 
5. Turner, K. B., and Steiner, A., A long term study of the variation of serum cholesterol in man. J. Clin. Invest., 1939, 18, 45.

6. Pomeranze, J., Beinfield, W. H., and Chessin, M., Serum lipid and fat tolerance studies in normal, obese, and atherosclerotic subjects. Circulation, 1954, 10, 742.

7. Jones, H. B., Gofman, J. W., Lindgren, F. T., Lyon, T. P., Graham, D. M., Strisower, B., and Nichols, A. V., Lipoproteins in atherosclerosis. Am. J. Med., 1951, 11, 358.

8. Bragdon, J. H., Havel, R. J., and Boyle, E., Human serum lipoproteins. I. Chemical composition of four fractions. J. Lab. \& Clin. Med., 1956, 48, 36.

9. Sperry, W. M., and Webb, M., A revision of the Schoenheimer-Sperry method for cholesterol determination. J. Biol. Chem., 1950, 187, 97.

10. Stewart, C. P., and Hendry, E. B., The phospholipins of blood. Biochem. J., 1935, 29, 1683.

11. Bragdon, J. H., Colorimetric determination of blood lipids. J. Biol. Chem., 1951, 190, 513.

12. Sperry, W. M., and Brand, F. C., The determination of total lipides in blood serum. J. Biol. Chem., 1955, 213, 69.

13. Unpublished data.

14. Carlson, L. A., and Wadström, L. B., On the occurrence of tri-, di-, and monoglycerides in human plasma. Biochemical Problems of Lipids, Proc. Third International Conference, Butterworths Scientific Publications, London. In press.
15. Havel, R. J., Eder, H. A., and Bragdon, J. H., The distribution and chemical composition of ultracentrifugally separated lipoproteins in human serum. J. Clin. Invest., 1955, 34, 1345.

16. Swank, R. L., and Wilmot, V., Chylomicra: Their composition and their fate after intravenous injection of small amounts of heparin. Am. J. Physiol., 1951, 167, 403.

17. van Eck, W. F., Peters, J. P., and Man, E. B., Significance of lactescence in blood serum. Metabolism, 1952, 1, 383.

18. Albrink, M. J., Glenn, W. W. L., Peters, J. P., and Man, E. B., The transport of lipids in chyle. J. Clin. Invest., 1955, 34, 1467.

19. Havel, R. J., and Fredrickson, D. S., The metabolism of chylomicra. I. The removal of palmitic acid1- $\mathrm{C}^{14}$ labeled chylomicra from dog plasma. J. Clin. Invest., 1956, 35, 1025.

20. Starke, H., Effect of the rice diet on the serum cholesterol fractions of 154 patients with hypertensive vascular disease. Am. J. Med., 1950, 9, 494.

21. Watkin, D. M., Froeb, H. F., Hatch, F. T., and Gutman, A. B., Effects of diet in essential hypertension. II. Results with unmodified Kempner rice diet in fifty hospitalized patients. Am. J. Med., 1950, 9, 441.

22. Mellinkoff, S. M., Machella, T. E., and Reinhold, J. G., The effect of a fat-free diet in causing low serum cholesterol. Am. J. M. Sc., 1950, 220, 203. 